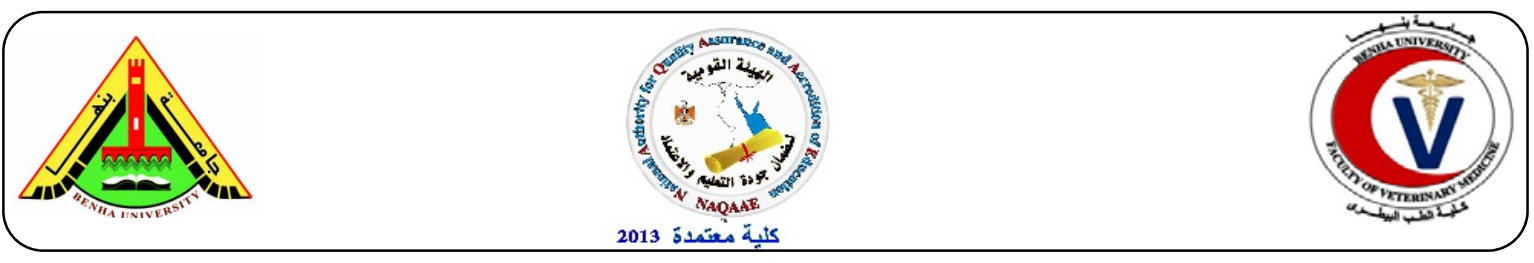

\title{
Typing of Clostridium perfringens isolated from some meat products by using PCR.
}

${ }^{1}$ Ashraf A. Abd Al- Tawab, ${ }^{1}$ Fatma I. El-Hofy, ${ }^{2}$ Dalia F. Khater and ${ }^{2}$ Mohamed A. M. Kotb

${ }^{1}$ Bacteriology, Immunology and Mycology Department, Faculty of Veterinary Medicine, Benha University. ${ }^{2}$ Animal Health Research Institute, Tanta branch

\section{A B S T R A C T}

One hundred and twenty random samples of meat products from different supermarkets in El-Gharbia governorate including minced meat, beef burger, sausage, luncheon (30 samples of each) were collected. C. perfringenswas detected in meat products with an incidence 15\%. The incidence of C.perfringens in minced meat, sausage, beefburger and luncheon was $16.67 \%, 23.33 \%, 16.67 \%$ and $3.33 \%$, respectively. Typing of C.perfringens isolates revealed that the incidences of toxigenic and non-toxigenic strains were $83.33 \%$ and $16.67 \%$, respectively. Typing of toxigenic strains of C.perfringens revealed that all isolates were type (A). Polymerase chain reaction (PCR) was applied for detection of toxin genes and enterotoxin of C.perfringens. All tested isolates were positive for alpha toxin gene with amplified PCR product of $402 \mathrm{bp}$ and were cpe negative. Public health importance of C.perfringens isolates was discussed.

Keywords: Clostridium perfringens, PCR, Meat products.

(http://www.bvmj.bu.edu.eg)

(BVMJ-29(1): 118-123, 2015)

\section{INTRODUCTION}

C lostridium perfringens is sporeforming anaerobic bacterium widespread in the environment frequently in the intestinal tract of man and animals. It is responsible for gastrointestinal and enterotoxaemic diseases in animals and food-poisoning and gas gangrene in man (Petit et al., 1999). C. perfringens has a great effect on the human health causing food poisoning; also C.perfringens causes a number of human diseases ranging from necrotic enteritis to wound infection and life threatening gas gangrene. This pathogenicity is associated with lethal extra cellular toxins which have been defined as enzyme activity as collagenase, hyaluronidase and deoxyribonuclease (Norrisand Pettipher, 1987). Usually, C.perfringens has been classified into five toxigenic types (A through $\mathrm{E}$ ) on the basis of its ability to produce major toxins (Yoo et al., 1997). Type A produces only alpha toxin, type B produces alpha, beta and epsilon toxins, type $\mathrm{C}$ produces alpha and beta toxins, type $\mathrm{D}$ produces alpha and .epsilon toxins and type E produces alpha and iota toxins. Each type of C.perfringens can cause different diseases. The most commonly encountered type A strain causes gas gangrene (myonecrosis), diarrhea, and food-borne illness in humans (Hatheway, 1990). Classically, typing of C. perfringens is performed with toxin neutralization with mice or guinea pigs (Stern and Batty, 1975 and McDonel, 1986). Because these methods are time consuming and expensive, they have largely been replaced by PCRbased detection methods. In recent years, molecular techniques such as polymerase chain reaction (PCR) have been used for typing of C.perfringens (Baums et al., 2004).

\section{MATERIAL AND METHODS}

\subsection{Samples collection:}

One hundred and twenty random meat product samplesincluding minced meat, 
beef burger, sausage and luncheon (30 of each) were collected from different supermarkets in El-Gharbia governorate. The samples were transferred to the laboratory for bacteriological examination.

\subsection{Bacteriological examination:}

\subsubsection{Isolation and Identification of C.perfringens:}

Each 2-3gm of sample was inoculated onto a tube of sterile freshly prepared cooked meat medium, and then the tube was incubated anaerobically in anaerobic jar using anaerobic gas generating kits at $37^{\circ} \mathrm{C}$ for 24-48 hours. For isolation of C.perfringens, a loopful from the previously incubated tube was streaked onto surface of $10 \%$ sheep blood agar with neomycin sulphate $(200 \mu \mathrm{g} / \mathrm{ml})$. The plate was incubated anaerobically at $37^{\circ} \mathrm{C}$ for 24 48 hours. Selected suspected colonies were transferred to tubes of freshly boiled and cooled cooked meat broth and was incubated anaerobically at $37^{\circ} \mathrm{C}$ for 24 hours to have pure culture of isolates for further identification. The plates were examined for thecharacteristic colonies of C.perfringens. Subcultures fromthe suspected colonies were identified morphologicallyand biochemically according to Smith and Holdman (1968) and Koneman et al. (1992). Vitek was used as a confirmatory biochemical tool.

\subsubsection{Typing of C.perfringens isolates:}

Positive strains of $C$. perfringens isolates were typed into toxigenic and non-toxigenic strains using dermonecrotic reaction test and toxin-antitoxin neutralization test (Smith and Holdman, 1968 and Stern and Batty, 1975).

\subsection{Determination of toxins and enterotoxin (cpe) genes of C.perfringens by using PCR:}

Oligonucleotide primers were used for detection of alpha, beta and epsilon toxins by conventional PCR according to Yoo et al. (1997).

\section{RESULTS}

\subsection{1. Incidence of C.perfringens in meat product samples:}

Out of 120 meat products samples collected from different supermarkets in El-Gharbia governorate, 18 C.perfringens isolates were detected with an incidence $15 \%$. The incidence of C.perfringens in sausage was $23.33 \%$ (7/30 samples), in minced meat was $16.67 \%$ (5/30 samples), in beef burger was $16.67 \%$ (5/30 samples) and in luncheon was $3.33 \%$ ( $1 / 30$ samples $)$.

\subsection{Identification of C.perfringens isolates:}

\subsubsection{Culture characters:}

C.perfringens on neomycin sulphate sheep blood agar, colonies were $2-3 \mathrm{~mm}$ in diameter, rounded, raised, glistening and showed double zone of hemolysis. On TSC agar, C.perfringens colonies were black in colour.On egg yolk agar medium, the attack of C.perfringens alpha toxin on lecithin gave opalescence on the side of the plate without antitoxin while this was inhibited on the other side of the plate with antitoxin.

\subsubsection{Biochemical identification:}

Results of sugar fermentation test revealed that the isolates were positive for glucose, lactose and sucrose sugars while mannitol fermentation was negative. C.perfringens isolates liquefied gelatin while catalase and indole were negative. Vitek 2 compact system confirmed isolates as C.perfringens.

\subsubsection{Typing of C.perfringens isolates:}

Typing of $C$. perfringens by intradermal injection of Guinea pig which revealed that the incidence of toxigenic and nontoxigenic strains were $83.33 \%$ (15 out of 18 isolates) and $16.67 \%$ (3 out of 18 isolates), respectively. Typing of C.perfringens revealed that toxigenic strains of isolated C.perfringens were detected in minced meat $(100 \%)$, sausages $(71.4 \%)$, beef burger $(80 \%)$ and luncheon $(100 \%)$. All isolated C.perfringens strains from meat products were type "A". Action of C.perfringens 
type "A" alpha toxin appeared as an irregular area of yellowish necrosis and tended to spread downward.

\subsection{Genotyping of C.perfringens isolates by using PCR:}

PCR was applied by using primers of alpha, beta, epsilon, iota and enterotoxin toxin genes to determine toxin- type of tested strains of C.perfringens isolated from sausages, beef burger, minced meat and luncheon. All tested samples were positive for alpha toxin gene with amplification of PCR product at $402 \mathrm{bp}$ in comparison with standard molecular size marker.

Table (1): Oligonucleotide primers used for detection of alpha, beta and epsilon toxins by conventional PCR

\begin{tabular}{clllc}
\hline Toxin & Primer & \multicolumn{1}{c}{ Sequence } & $\begin{array}{c}\text { Amplified } \\
\text { product }\end{array}$ & Reference \\
& & & \\
\hline Alpha toxin & $c p a(F)$ & GTTGATAGCGCAGGACATGTTAAG & $402 \mathrm{bp}$ & Yoo et al., 1997 \\
& $c p a(\mathrm{R})$ & CATGTAGTCATCTGTTCAGCATC & & \\
Beta toxin & $c p b(\mathrm{~F})$ & ACTATACAGACAGATCATTCAACC & $236 \mathrm{bp}$ & \\
& $c p b(\mathrm{R})$ & TTAGGAGCAGTTAGAACTACAGAC & & \\
Epsilon toxin & $c p c(\mathrm{~F})$ & ACTGCAACTACTACTCATACTGTG & \multirow{2}{*}{$541 \mathrm{bp}$} & \\
& $c p c(\mathrm{R})$ & CTGGTGCCTTAATAGAAAGACTCC & & \\
Iota toxin & $c p d(\mathrm{~F})$ & GCGATGAAAAGCCTACACCACTAC & \multirow{2}{*}{$317 \mathrm{bp}$} & \\
& $c p d(\mathrm{R})$ & GGTATATCCTCCACGCATATAGTC & & \\
Enterotoxin & $c p e(F)$ & GGAGATGGTTGGATATTAGG & $233 \mathrm{bp}$ & Heikinheimo \\
& $c p e(\mathrm{R})$ & GGACCAGCAGTTGTAGATA & & and Korkeala, \\
& & & & 2005 \\
\hline
\end{tabular}

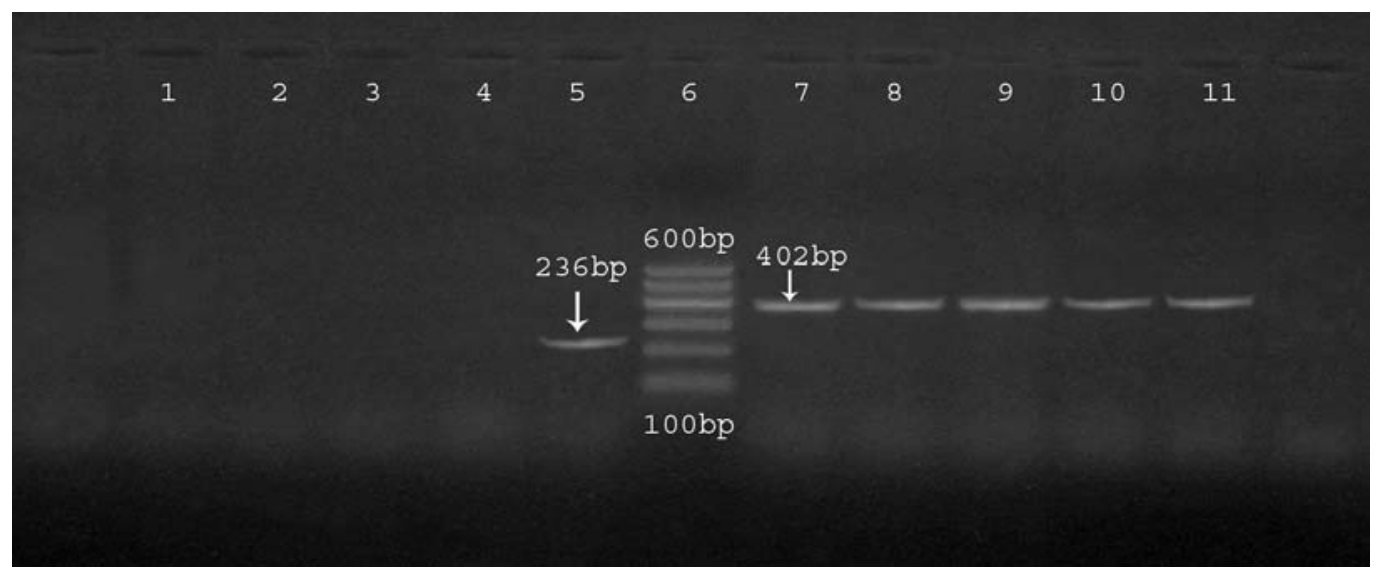

Figure (1): PCR of $\alpha$ and $\beta$ toxins encoded genes of C.perfringens,

PCR products (402bp for alpha and 236bp for beta). Lane 5: positive control for $\beta$ toxin gene. Lane 6: standard molecular size marker (100bp - 600bp). Lane 7: positive control for $\alpha$ toxin gene. Lane $8,9,10,11$ are positive for $\alpha$ toxin gene at $402 \mathrm{bp}$. 


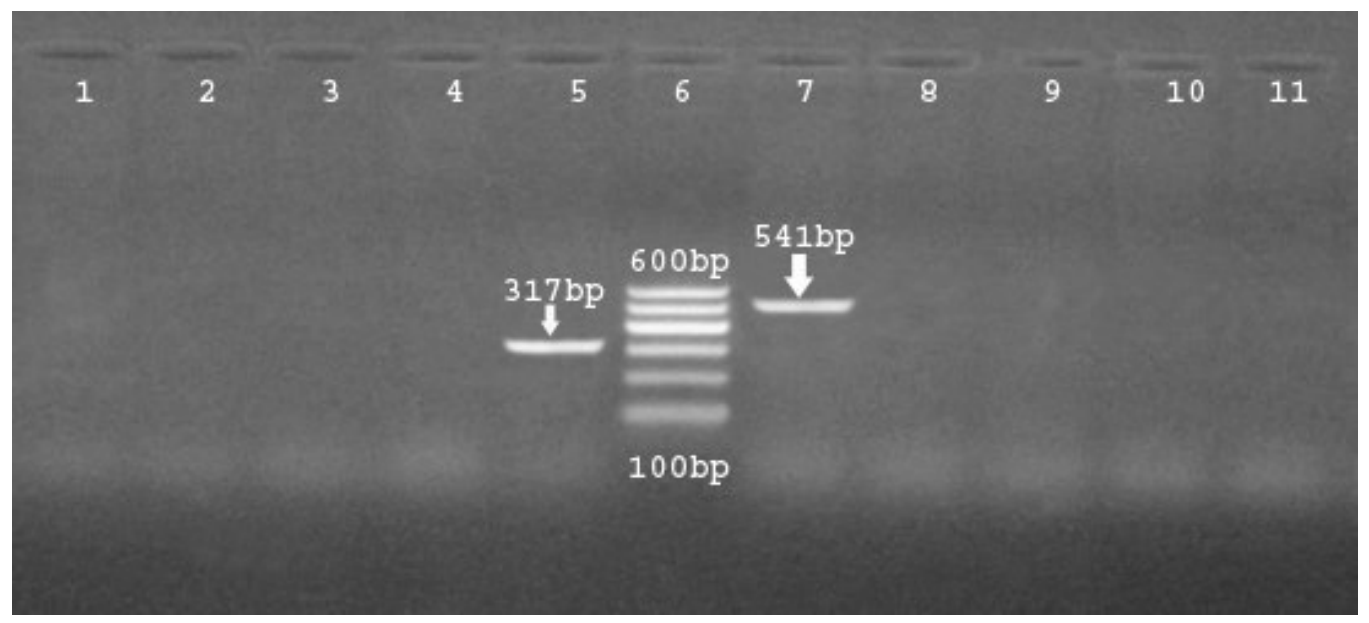

Figure (2): PCR of epsilon and iota toxins encoded genes of C.perfringens, PCR products (541bp for $\varepsilon$ and 317bp for 1 ). Lane 5: positive control for 1 toxin gene. Lane 6: standard molecular size marker (100bp - 600bp). Lane 7: positive control for $\varepsilon$ toxin gene.

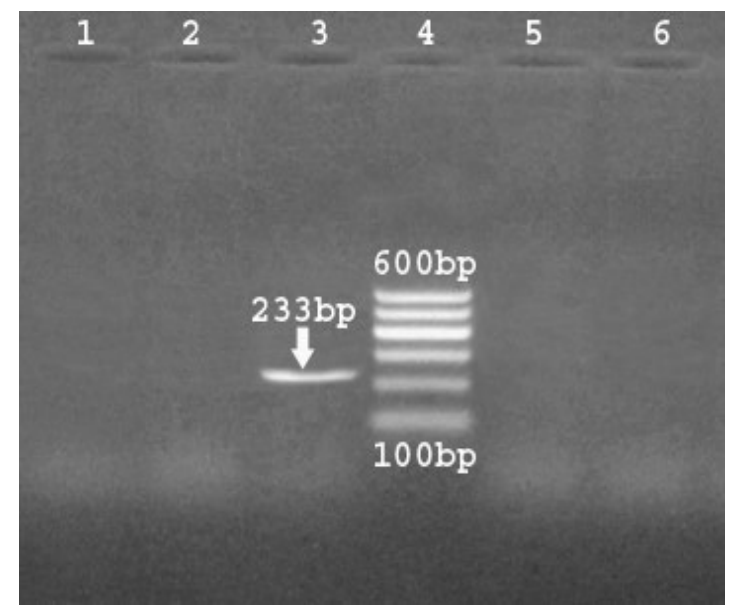

Figure (3): PCR of enterotoxin encoded gene of C.perfringens. Lane 3: positive control for enterotoxin gene. Lane4: standard molecular size marker.

\section{DISSCUSION}

Food illness caused by C.perfringens is among the common illnesses resulting from the consumption of contaminated food, the vehicles of infection are typically meat and poultry products. It has been firmly established that an enterotoxin produced in the intestine following sporulation of ingested vegetative cells is responsible for the illness (Duncan, 1973). In the present study, incidence of $C$. perfringens in sausage was $23.33 \%$. This result was completely agreed with (Hassanien, 2004 and El Shater, 2010) who found that incidence of $C$. perfringens in sausage was $24 \%$. Similar results obtained by El Khateib (1997) who recorded isolation of C.perfringens from sausage were in percentage of $26 \%$. In the current study, the incidence of C.perfringens in beef burger was $16.67 \%$. This resultwas completely agreed with Fatein (2001) and Elewia (2003) who found the incidence of C.perfringens in beef burger was $16 \%$. Nearly similar results were obtained by Elmossalami (2003) who found that incidence in beef burger was $20 \%$ but these results vary too much between authors who reported different percentage of isolation, 
Edris (1992) stated isolation of C.perfringens from beef burger in percentage of $90 \%$. Results showed that isolation of C.perfringens from minced meat was $16.67 \%$. A similar result obtained by Hamoda (2012) who stated the incidence of C.perfringens in minced meat was $20 \%$. Higher result was obtained by Alkheraije (2013) who recorded that incidence in minced meat was $46 \%$ but Lower results were recorded by Herrer (1995) who isolated C.perfringens from minced meat with percentage of $7.1 \%$. Results showed that the incidence of C.perfringens in luncheon was $3.33 \%$. Similar result was obtained by Khater (2004) who found the incidence of C.perfringens in luncheon in plane II was $5 \%$. Higher result was obtained by Khairy (2005) who found the incidence of C.perfringens in luncheon was $65 \%$. The incidence of toxigenic and non-toxigenic strains was $83.33 \%$ and $16.67 \%$, respectively. These results came in agreement with Hamoda (2012) who recorded that the incidence by intradermal injection of toxigenic and non-toxigenic strains were $81 \%$ and $11.9 \%$, respectively while Atwa and Abou EI-Roos (2011) found that Typing of $C$. perfringens revealed that the incidences of toxigenic and non-toxigenic strains were 89.6 and $10.4 \%$.Typing of toxigenic strains of C.perfringens was revealed that all isolates were Type "A". Those results completely agreed with Emara (2014). PCR is more accurate and faster than the other normal methods for isolation and identification of causative agents(Aschfalk and Muller, 2002).It has been proved to be a very sensitive and specific technique for detection of the genes encoding alpha and epsilon exotoxin as well as enterotoxin of C.perfringens for rapid typing and evaluation of the virulence of the microorganism (Petit et al., 1999). In present study, all tested C.perfringens isolates gave characteristic band at $402 \mathrm{bp}$ i.e. all isolates were positive for gene encoding alpha toxin as. The results go hand in hand with Augustynowicz et al., (2000) who found that C.perfringens alpha toxin gene amplicon was the only one that recorded in all tested isolates and gave a characteristic band at 402bp.

\section{CONCLUSION}

C.perfringens type A was the most predominant one and it is main cause for food poisoning outbreaks. In this study, PCR was used for diagnostic purpose, as it is much faster and more accurate than conventional microbiological techniques.

\section{REFERENCES}

Alkheraije, K.H. 2013. Some characters of C.perfringens isolated from fresh and marketed processed meat. Open Journal of veterinary medicine (3): 187-191.

Aschfalk, A., Muller, W. 2002. Clostridium perfringens toxin types from wildcaught Atlantic cod (Gadusmorhua L.), determined by PCR and ELISA. Can. J. Microbiol., 48(4):365-368.

Atwa, E.I., Abou-El Ross, N.A. 2011. Incidence of Clostridium perfringens in meat products at some Egyptian governorates. International Journal of Microbiological Research 2 (3): 196203.

Augustynowicz, E., Gzyl, A., Slusarczyk, J. 2000. Molecular epidemiology survey of toxinogenic Clostridium perfringens strain types by multiplex PCR. Scand. J. Infect. Dis., 32:637641.

Baums, C.G., Schotte, U., Amtsberg, G., Goethe, R. 2004. Diagnostic multiplex PCR for toxingenotyping of C.perfringens isolates. Vet. Lab. Diag. and OIE seminar, Biotech., 9(13):99-100.

Edris, A.M., El- Bardisy, M., Mousa, M.M. 1992. Studies on microbial status of some market meat products with special reference to C.perfringens. Egypt. J. App. Sci., 7: 19-30. 
Eleiwa, N.Z. 2003. Effect of chemical preservatives on food poisoning bacteria in some locally manufactured meat products. Ph.D. V. Sc. Meat Hygiene. Thesis, Fac. Vet. Med., Zagazig Univ., Benha branch

El-Khateib, T. 1997. Microbiological status of Egyptian salted meat (basterma) and fresh Sausage. J. of food safety, 17(3):141- 150.

El-Mossalami, E. 2003. Risk assessment of ready prepared meat products. Ph.D. Meat Hygiene. Thesis, Fac. Vet. Med., Cairo Univ.

El-Shater, N.S.L. 2010. Evaluation of immunological and bacteriological patterns of some food poisoning micro-organisms (Staphylococcus aureus and Clostridium perfringens). Ph.D. V. Sc. (Immunology), Fac. Vet. Med. Zagazig Univ.

Emara, M.S.E.M.M. 2014. Anaerobic and Aerobic microorganisms in human Food. M. V. Sc. Thesis (Bacteriology, Immunology and Mycology), Fac. Vet. Med., Cairo Univ.

Fatein, S.H., El-Taher, E.M., Ibrahim, H.M. 2001. Occurrence of Clostridium perfringens in some meat products in Sharkia and Kalyobia governorates. Mansoura veterinary medical journal, 3(2):109-117.

Hamoda, W.S.A.O. 2012. Study on the effect of some spices and organic salts on Clostridium perfringens during cooling of raw and cooked ground beef. M. V. Sc. Thesis (Bacteriology), Fac. Vet. Med., Zagazig Univ.

Hassanien, F.S. 2004. Bacterial hazards associated with consumption of some meat Products. Benha Vet. Med. J., 15 (2).

Hatheway, C.L. 1990. Toxigenic clostridia. Clin. Microbiol. Rev., 3: 66- 98.

Heikinheimo, A., Korkeala, H.2005. Multiplex PCR assay for toxinotyping Clostridium perfringens isolates obtained from Finnish broiler

chickens. Letters in Applied Microbiology. 40: 407-411.

Herrer, S.I. 1995.Quality of fresh beef, lamb, pork and similar meat products. Alimentaria, 265:83-85.

Khairy, D.I. 2005.Studies on C.perfringens in some meat products. Ph.D. V. Sc. (Microbiology), Fac. Vet. Med. Cairo Univ.

Khater, D.F. 2004. Studies on microbial toxins in some vacuum packed meat products. Ph.D. V. Sc. Meat Hygiene. Thesis, Fac. Vet. Med., Zagazig Univ., Benha branch.

Koneman, E.W., Allen, S.D., Dowell, V.R., Summers, H.W. 1992. "Color atlas and text book of diagnostic microbial.”2 $2^{\text {nd }}$ Ed., J. B. Lippin Cott, New York, London.

McDonel, J.L. 1986. Toxins of Clostridium perfringens types $\mathrm{A}, \mathrm{B}, \mathrm{C}, \mathrm{D}$, and $\mathrm{E}$. In Pharmacology of Bacterial Toxins ed., Dorner, F. and Drews, H. pp. 477-517. Oxford: Pergamon Press.

Norris, J.R., Pettipher, G.L. 1987.Essays in agricultural and food microbiology. $1^{\text {st }}$ Ed., Chichester, New York, Brisbane.

Petit, L., Gibert, M., Pop off, M.R.1999.Clostridium perfringens: toxinotype and genotype. Trends. Microbiol., 7: 104-110.

Smith, L.D.S., Holdman. 1968. "The pathogenic anaerobic bacteria." $1^{\text {st }}$ Ed. 201-255. Charles Thomas Publisher, USA.

Stern, M., Batty, I. 1975. "Pathogenic Clostridia. "Butter Worth, London, Boston.

Yoo, H.S., Lee, S.U., Park, K.Y., Park, Y.H. 1997. Molecular typing and epidemiological survey of prevalence of Clostridium perfringens types by multiplex PCR. J. clin. Microbiol., 35(1):228-232. 